\title{
Prevalence and factors associated with urinary incontinence in climacteric
}

\author{
Máyra Cecilia Dellứ $1 *$, Ana Carolina Basso Schmitt² ${ }^{2}$, Maria Regina Alves Cardoso ${ }^{3}$, Wendry Maria Paixão Pereira ${ }^{1,4}$, \\ Elaine Cristina Alves Pereira4 ${ }^{4}$, Érika da Silva Flauzino Vasconcelos ${ }^{5}$, José Mendes Aldrighi ${ }^{6}$ \\ ${ }^{1}$ PhD - Lecturer of the Department of Physiotherapy, Universidade de Taubaté (Unitau), Taubaté, SP, Brazil \\ ${ }^{2}$ PhD - Lecturer of the Department of Physical Therapy, Speech Therapy, and Occupational Therapy, Faculdade de Medicina, Universidade de São Paulo (FMUSP), São Paulo, SP, Brazil \\ ${ }^{3} \mathrm{PhD}$ - Lecturer of the Department of Epidemiology, Faculdade de Saúde Pública, Universidade de São Paulo (FSP/USP), São Paulo, SP, Brazil \\ ${ }^{4} \mathrm{PhD}$ - Lecturer at Fundação Universitária Vida Cristã, Pindamonhangaba, SP, Brazil \\ ${ }^{5} \mathrm{MSc}$ - Lecturer at Fundação Universitária Vida Cristã, Pindamonhangaba, SP, Brazil \\ ${ }^{6} \mathrm{PhD}$ - Lecturer of the Department of Mother and Child Health, FSP/USP, São Paulo, SP, Brazil
}

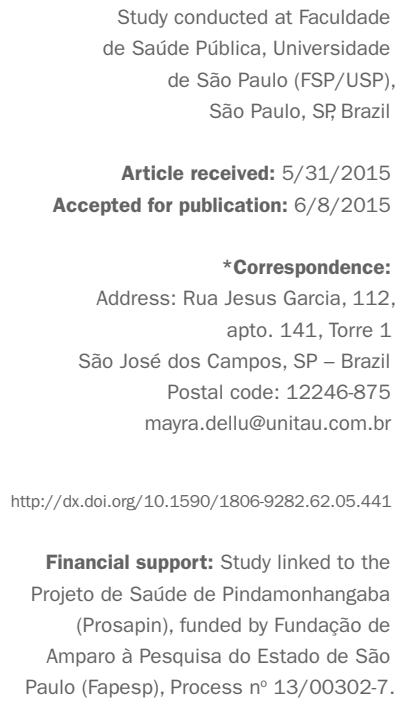

Article received: $5 / 31 / 2015$ Accepted for publication: 6/8/2015

*Correspondence: Address: Rua Jesus Garcia, 112 apto. 141, Torre 1 São José dos Campos, SP - Brazil Postal code: $12246-875$ mayra.dellu@unitau.com.br

http://dx.doi.org/10.1590/1806-9282.62.05.441

Financial support: Study linked to the Projeto de Saúde de Pindamonhangaba

(Prosapin), funded by Fundação de

Amparo à Pesquisa do Estado de São Paulo (Fapesp), Process n 13/00302-7.

\section{SUMmARY}

Objective: To estimate the prevalence and identify associated factors to urinary incontinence (UI) in climacteric women.

Method: In a cross-sectional study with a stratified random sample, 1,200 women aged between 35 and 72 years were studied, enrolled in the Family Health Strategy in the city of Pindamonhangaba, São Paulo. Urinary incontinence was investigated using the International Consultation of Incontinence Questionnaire - Short Form, while associated factors were assessed based on a self-reported questionnaire with socio-demographic, obstetric and gynecological history, morbidities and drug use. The prevalence of urinary incontinence was estimated with a $95 \%$ confidence interval (95CI) and the associated factors were identified through multiple logistic regression model performed using Stata software, version 11.0.

Results: Women had a mean age of 51.9 years, most were in menopause (59.4\%), married (87.5\%), Catholic (48.9\%), and declared themselves black or brown (47.2\%). The mean age of menopause of women with UI was 47.3 years. The prevalence of UI was 20.4\% (95CI: 17.8-23.1\%). The factors associated with UI were urinary loss during pregnancy $(\mathrm{p}=0.000)$ and after delivery $(\mathrm{p}=0.000)$, genital prolapse $(\mathrm{p}=0.000)$, stress $(\mathrm{p}=0.001)$, depression $(\mathrm{p}=0.002)$, and obesity $(\mathrm{p}=0.006)$.

Conclusion: The prevalence of UI was lower but similar to that found in most similar studies. Factors associated with the genesis of UI were urinary loss during pregnancy and after delivery, genital prolapse and obesity.

Keywords: prevalence, urinary incontinence, climacteric, health surveys.

\section{INTRODUCTION}

Women's health in the climacteric has been widely investigated and discussed, not only because of clinical repercussions that affect the quality of life of women, but also for the significant impact on public health.

Climacteric results from ovarian follicular depletion, with consequent reduction in the production of estrogen, during which time women may experience uncomfortable symptoms such as hot flashes, mood disorders, insomnia, skin and mucosal atrophy, and serious health problems such as cardiovascular disease, osteoporosis ${ }^{1}$ and genitourinary disorders, including vaginal, sexual and urinary symptoms such as urinary incontinence (UI). ${ }^{2}$
Estimates of prevalence of UI vary considerably, ranging from 12 to $51 \%$, depending on the concept of UI, research methodologies, inclusion criteria, such as age and ethnicity, and type of incontinence studied..$^{3-7}$ In Brazil, data on prevalence of UI in middle aged women usually relate to stress UI (SUI), reaching 8 to $48 \% .^{8-14}$

Moreover, there is a disturbing economic impact on the health system, seen, for example, in the costs in Brazil in 2014; the total spent on women between 30 and 59 years totaled more than BRL 2 billion, and of these, BRL 183 million were directed to genitourinary diseases. Surgeries for female genital prolapse, one of the causes of UI included in the ICD10 , generated in 2014 a cost of BRL 15.8 million (8.7\%). ${ }^{15}$ 
It is thus clear that, although the disease does not constitute risk for women, ${ }^{16}$ UI promotes significant impact on their quality of life and the health system in Brazil. ${ }^{17}$ Therefore, it is important to know the factors associated with the appearance of the UI, aiming to develop prevention strategies in primary health care.

\section{Method}

In this cross-sectional study, a population group of women aged 35 to 72 years was studied based on the Projeto de Saúde de Pindamonhangaba (Prosapin) database. The Prosapin I began operating in 2007 after a scientific technical cooperation agreement signed in 2014 with the Municipal Health Department (MHD) of Pindamonhangaba. The present Prosapin II (2014) was approved by the Ethics in Research Committee of FSP/USP, ${ }^{18}$ and included a probability sample selected using systematic sampling procedure. The sample was composed of women between 35 and 65 years enrolled in a Family Health Program (FHP) of Pindamonhangaba, initially sorted according to age and the health unit where they were enrolled. In 2014, according to the Health Department, the city had a basic health care network consisting of 21 family health teams that gave coverage to $39.9 \%$ of the population. ${ }^{19,20}$

Thus, 1,200 women participated in the project, with some belonging to Prosapin I (2007) and in the same age range, plus new participants selected in 2014. After excluding 202 women, 998 were interviewed. The reasons for exclusion were cognitive problems, changes of address and death.

The UI variable was investigated using the International Consultation on Incontinence Questionnaire - Short Form (ICIQ-SF) which assesses the presence and possible situations of involuntary loss of urine, and the impact of UI in the previous month. ${ }^{21}$ The ICIQ-SF comprises four items: (1) urinary frequency; (2) volume; (3) impact of UI on daily life ("0" none, "1 to 3" mild, "4 to 6" moderate, "7 to 9" severe, " 10 " very severe); (4) urinary symptoms. ${ }^{22}$ The ICIQ-SF ranges from 0 to 21 points, and all women whose total score was greater than or equal to 1 were considered incontinent.

Anthropometric measurements (weight, height) and interviews were conducted to obtain information on sociodemographic characteristics, gynecological history and medication use that could interfere with bladder functioning. Morbidities were also investigated using validated instruments for depression (Beck Depression Inventory), ${ }^{23}$ stress (Stress Symptoms Inventory), ${ }^{24}$ obesity (World Health Organization obesity classification), ${ }^{25}$ genital prolapse (International Consultation on Incontinence Questionnaire - Vaginal Symptoms). ${ }^{26}$
A database was constructed on Microsoft Office Excel 2008, to store the collected data. The prevalence of UI in postmenopausal women was estimated within a $95 \%$ confidence interval. Bivariate analyzes were conducted to identify possible factors associated with the dependent variables. A multiple logistic regression model was constructed to estimate the net weight of each independent variable.

\section{Results}

The mean age of the women was 51.9 years ( $\mathrm{SD}=8.8$ years) and the mean age at menopause of the women with UI was 47.3 years ( $\mathrm{SD}=5.8$ years). There was a higher proportion of women aged 55 or older (39.3\%); $59.4 \%$ were in menopause, $84.4 \%$ were married, Catholic $57.8 \%$, and $48.7 \%$ declared themselves as white. With regard to formal education, more than a third studied until the fourth grade (primary education), and more than half studied up to six years. With regard to occupation, more than half were active (51.1\%), mainly in domestic services (66.8\%). Only $3.5 \%$ were retired or pensioners, and $45 \%$ earned the minimum wage or less.

The prevalence of UI was $20.4 \%$ (95CI: $17.8-23.1 \%)$. The mean age of onset of UI was 48 years ( $\mathrm{SD}=10.8$ years), ranging from 20 to 70 years. As for types of urine leakage, mixed incontinence was the most frequent (19.2\%), followed by stress incontinence $(15.9 \%)$ and urge incontinence (14.6\%).

Considering socio-demographic factors, only skin color was positively associated with $\mathrm{UI}(\mathrm{p}=0.036)$. An inverse association was observed for education level above the high school $(\mathrm{p}=0.036)$ and having seven or more years of study ( $\mathrm{p}=0.019)$. Age showed no relationship with UI in our study.

Obstetric factors that are positively associated with UI included pregnancy $(\mathrm{p}=0.000)$ and post-partum $(\mathrm{p}=0.000)$ incontinence, three or more pregnancies $(\mathrm{p}=0.001)$, and giving birth to children weighing more than $3.5 \mathrm{~kg}(\mathrm{p}=0.015)$. As for gynecological history, recurrent urinary tract infection $(\mathrm{p}=0.000)$, gynecologic surgery $(\mathrm{p}=0.002)$ and a family history of UI $(0.017)$ were positively associated with urinary loss. The association between UI and parity, mode of delivery, use of forceps, performing episiotomies and menopause was not observed.

The presence of genital prolapse $(\mathrm{p}=0.000)$, vaginal symptoms $(\mathrm{p}=0.000)$, stress $(\mathrm{p}=0.000)$, obesity $(\mathrm{p}=0.008)$, depression $(\mathrm{p}=0.000)$ and anxiety $(\mathrm{p}=0.000)$ was positively associated with involuntary loss of urine. The use of drugs was also associated with UI, especially when equal 
to or greater than three drugs $(\mathrm{p}=0.000)$, in addition to drugs that may influence bladder function $(\mathrm{p}=0.012)$.

Based on logistic regression model (Table 1), we can observe that menopause was not associated with UI, unlike variables such as pregnancy $(\mathrm{p}=0.000)$ and post-partum $(\mathrm{p}=0.000)$ incontinence, genital prolapse $(\mathrm{p}=0.000)$, obesity $(\mathrm{p}=0.006)$, stress $(\mathrm{p}=0.001)$ and depression $(\mathrm{p}=0.002)$.

\section{Discussion}

Although UI is considered a major health problem, public policies are still occult.

The prevalence of UI in our study was $20.4 \%$, similar to the 25 to $51 \%$ of most studies with similar sample sizes including women in the same age range. ${ }^{4,27-29}$ Only the study by Misha et al. ${ }^{1}$ had a lower prevalence and reached $11 \%$.

In Brazil, the literature is scarce in investigations involving epidemiological data on UI, which generally relate to the specific type of chronic SUI, with prevalence ranging from 15 to $35 \% .{ }^{8,10,14,30}$ In our study, SUI affected $15.9 \%$ of climacteric women and was similar to the population findings by Brito et al. ${ }^{8}$

With regard to factors associated with UI, the literature is controversial and often shows association between UI and socio-demographic data such as age, education and race; obstetric factors such as pregnancy, multiparity, type of delivery, newborn weight; gynecological factors such as gynecological surgeries and menopausal status; and morbidities such as diabetes mellitus and obesity. ${ }^{1,4727-31}$ The bivariate analysis performed in our study showed a positive association with education, skin color, pregnancy, gynecologic surgery, which was not confirmed in the logistic regression. Our findings are in line with those documented by Brito et al. ${ }^{8}$ and Guarisi et al., ${ }^{14}$ who also found no association between UI and socioeconomic and reproductive factors.
We noted that UI in climacteric women was associated with urinary loss complaints during pregnancy and after childbirth, and also vaginal dystopia, depression, stress and obesity.

With regard to pregnancy UI, even though the mechanism of pelvic dysfunction is not completely understood, it is believed that initiating a pregnancy while being overweight or obese, ${ }^{32}$ on top of the additional weight that can be put on in this period, may lead to UI caused by tension, stretching or weakening of the tissues in the pelvic floor, ${ }^{29}$ increase in intra-abdominal pressure, and pudendal nerve dysfunction. ${ }^{33}$

Furthermore, the uterine growth coupled with endocrine changes, such as increasing progesterone, reduced relaxin and collagen may contribute to the reduction of muscle strength and support of the local sphincter function. ${ }^{34}$ Moreover, the mode of delivery may determine different degrees of muscle, nerve and connective tissue injury with increased risk of genital dystopia and involuntary loss of urine throughout life. ${ }^{35}$

Despite evidence showing that pelvic floor dysfunction arise in part from changes determined by the pregnancy and delivery, ${ }^{36-39}$ our study failed to confirm this association and signaled that only the involuntary loss of urine during and after delivery are associated with a higher prevalence of UI. Liang et $\mathrm{al}^{40}$ admit that the musculoskeletal structural adjustments of pregnancy and the anatomical and functional alterations of the pelvic floor that occur during the second stage of labor can gradually regress, thus returning to pre-pregnancy state, with partial or complete restoration of the mechanism of urinary continence.

Hilde et al., ${ }^{41}$ in turn, report that soon after vaginal delivery, in addition to the reduced vaginal tonus, strength and endurance of the pelvic floor, the floor of the continents mothers is much stronger than in those with UI in the same

TABLE 1 Logistic regression model between urinary incontinence and the epidemiological and clinical variables of women at Prosapin, Pindamonhangaba, 2014.

\begin{tabular}{lllllll} 
& UI & & & & & \\
& OR & $(\mathbf{9 5 C l})$ & $\mathbf{P}$ & $\mathbf{O R}$ & $\mathbf{( 9 5 \mathbf { C l } )}$ & $\mathbf{P}$ \\
\hline Menopause & 1.16 & $(0.83-1.62)$ & 0.365 & 1.24 & $0.84-1.82$ & 0.268 \\
\hline UI, pregnancy & 4.41 & $(2.88-6.74)$ & 0.000 & 2.58 & $1.59-4.18$ & 0.000 \\
\hline UI, post-partum & 6.90 & $(3.30-14.41)$ & 0.000 & 5.66 & $2.45-13.09$ & 0.000 \\
\hline Genital prolapse & 3.92 & $(2.79-5.51)$ & 0.000 & 2.53 & $1.71-3.75$ & 0.000 \\
\hline Stress & 3.81 & $(2.53-5.74)$ & 0.000 & 2.34 & $1.43-3.84$ & 0.001 \\
\hline Depression & 3.68 & $(2.57-5.29)$ & 0.000 & 1.96 & $1.28-3.01$ & 0.002 \\
\hline Obesity & 1.83 & $(1.17-2.86)$ & 0.008 & 1.68 & $1.15-2.43$ & 0.006 \\
\hline
\end{tabular}

UI: urinary incontinence; OR: odds ratio; $95 \mathrm{Cl}$ : $95 \%$ confidence interval; * OR adjust: odds ratio adjusted according to the remaining variables in the table. 
period. Involuntary loss of urine seems to be independent of the type of delivery, ${ }^{43}$ it can occur between two and twelve months after delivery ${ }^{42}$ and persist for many years. ${ }^{36}$

Our study showed a clear association between UI and genital dystopia, a result similar to those found in other studies. ${ }^{44-47}$ Genital dystopia is characterized by herniation of the pelvic and/or intraperitoneal content into the vaginal canal. ${ }^{48}$ It is a common injury in older multiparous women. It occurs due to relaxation of pelvic floor structures caused either by estrogen deficiency or aging, and results in the inability to maintain the pelvic organs in their normal position. ${ }^{49}$

Most women with UI in our study were multiparous, in menopause, and gave birth vaginally; their mean age was 52.8 years. While all of these factors can contribute to UI, multiple logistic regression shows that only pregnancy and parity were not associated with it.

Our results reveal that about $40 \%$ of women with UI had $\mathrm{BMI} \geq 30.0 \mathrm{~kg} / \mathrm{m}^{2}$, which is similar to the findings of other studies based on evidence that obesity affects sphincter control. ${ }^{1,33,50-52}$ Women with very high BMI scores ${ }^{33,53}$ and weight gain during perimenopause ${ }^{54}$ have a higher risk of UI, which can be reduced as soon as the excess weight is lost. ${ }^{33}$

Pathophysiological mechanisms of obesity leading to UI primarily include those of mechanical and/or neuroendocrine nature. The explanatory sequence would be obesity, increased intra-abdominal pressure, increased intravesical pressure, increased muscle tension in the pelvic floor, changes in muscle ligamentous structures and urethral mobility, stimulus by the afferent response of the bladder to the central nervous system, and onset of urinary symptoms such as urgency, frequency and probably incontinence. ${ }^{53,55,56}$

We showed that stress and depression were associated with UI, possibly due to embarrassment and social isolation caused by urinary loss. ${ }^{57}$

From the above, it is understood that the present study may contribute as an epidemiological reference in Brazilian literature and allow the targeting of interventions already in primary care.

Considering the magnitude of the problem, our study deserves special attention, because the population included reflects the sociodemographic and clinical characteristics of a large proportion of women living in small and medium-sized cities in the state of São Paulo and Brazil. Also, we must consider that in 2014 the FHP covered on average $59.8 \%$ of the Brazilian population ${ }^{15}$ and almost all of the country's municipalities (95\%) are small or medium, ${ }^{19}$ which reinforces the importance of our study.

\section{Conclusion}

Prevalence of UI was lower but similar to that found in most similar studies. Factors associated with the onset of UI included pregnancy and post-partum incontinence, genital prolapse and obesity, while consequences included depression and stress. Proper understanding of urinary incontinence in climacteric will certainly contribute to propose preventive strategies in primary health care. Therefore, early intervention, as soon as in prenatal care, in order to preserve pelvic floor function in climacteric should always be considered.

\section{ACKNOWLEDGMENTS}

To the Department of Health in Pindamonhangaba, SP, Brazil; Fundação de Amparo à Pesquisa do Estado de São Paulo (Fapesp), São Paulo; Universidade de Taubaté (Unitau), Taubaté, SP, Brazil; and the Coordenação de Aperfeiçoamento de Pessoal de Nível Superior (Capes).

\section{Resumo}

Prevalência e fatores associados à incontinência urinária no climatério

Objetivo: estimar a prevalência e identificar os possíveis fatores associados à incontinência urinária (IU) em mulheres no climatério.

Método: em estudo analítico transversal com amostra aleatória estratificada, foram estudadas 1.200 mulheres, entre 35 e 72 anos, cadastradas na Estratégia de Saúde da Família do município de Pindamonhangaba, SP. A IU foi investigada por meio do International Consultation of Incontinence Questionnaire - Short Form e os fatores associados, por meio de questionário autorreferido, contendo informações sociodemográficas, história ginecológica e obstétrica, morbidades e uso de medicamentos. Estimou-se a prevalência da incontinência urinária com intervalo de confiança de 95\% (IC95\%), e os fatores associados foram identificados por meio de um modelo de regressão logística múltipla realizada no Programa Stata, versão 11.0 .

Resultados: as mulheres apresentavam média etária de 51,9 anos, estavam na menopausa (59,4\%), eram casadas (87,5\%), católicas $(48,9 \%)$ e declararam-se negras ou pardas $(47,2 \%)$. A média de idade da menopausa das mulheres com IU foi de 47,3 anos. A prevalência de IU foi de 20,4\% (IC95\%: 17,8-23,1). Os fatores associados à IU foram perda urinária na gestação $(\mathrm{p}=0,000)$ e no pós-parto $(\mathrm{p}=0,000)$, prolapso genital $(\mathrm{p}=0,000)$, estresse $(\mathrm{p}=0,001)$, depressão $(p=0,002)$ e obesidade $(p=0,006)$. 
Conclusão: a prevalência de IU foi inferior, mas semelhante à encontrada na maioria dos estudos análogos. Os fatores associados à gênese da IU foram perda urinária na gestação e no pós-parto, prolapso genital e obesidade.

Palavras-chave: prevalência, incontinência urinária, climatério, inquéritos epidemiológicos.

\section{References}

1. Mishra GD, Cardozo L, Kuh D. Menopausal transition and the risk of urinary incontinence: results from a British prospective cohort. BJU Int. 2010; 106(8):1170-5.

2. Shifren JL, Gass ML. The North American Menopause Society recommendations for clinical care of midlife women. Menopause. 2014; 21(10):1038-62.

3. Rebassa M, Taltavull JM, Gutiérrez C, Ripoll J, Esteva A, Miralles J, et al.; Grupo de Estudio de la Incontinencia Urinaria en Mallorca. Urinary incontinence in Mallorcan women: prevalence and quality of life. Actas Urol Esp. 2013; 37(6):354-61.

4. Ahmed HM, Osman VA, Al-Alaf SK, Al-Tawil NG. Prevalence of urinary incontinence and probable risk factors in a sample of kurdish women. Sultan Qaboos Univ Med J. 2013; 13(2):269-74.

5. Hunskaar S, Burgio K, Diokono A, Herzog R, Hjalmas K, Lapitan MC. Epidemiology and natural history of urinary incontinence in women. Urology. 2003; 62(4 Suppl 1):16-23

6. Peyrat L, Haillot PO, Bruyere F, Bertrand P, Lanson Y. Prevalence and risk factors of urinary incontinence in young and middle-aged women. BJU Int. 2002; 89(1):61-66

7. Hannestad YS, Rortveit G, Sandvik H, Hunskaar S. Community-based epidemiological survey of female urinary incontinence: The Norwegian EPICONT Study. Epidemiology of Incontinence in the County of NordTrøndelag. J Clin Epidemiol. 2000; 53(11):1150-7.

8. Brito LG, Brito LM, Chein MB, Malheiros ES, Duarte TB, Pinto-Neto AM. Stress urinary incontinence in climacteric women in a Northeastern Brazilian municipality: a household survey. Int Urogynecol J. 2012; 23(5):639-45.

9. Sacomori C, Negri NB, Cardoso FL. [Urinary incontinence in women undergoing Pap smear test: socio-demographic and behavioral factors]. Cad Saúde Pública. 2013; 29(6):1251-9.

10. Machado VSS, Valadares AL, Paiva LSC, Osis MJ, Sousa MH, Pinto-Neto AM. Aging, obesity, and multimorbidity in women 50 years or older: a population-based study. Menopause. 2013; 20(8):818-24.

11. Santos CRS, Santos VLCG. [Prevalence of urinary incontinence in a random sample of the urban population of PousoAlegre, Minas Gerais, Brazil]. Rev Latino-Am Enfermagem. 2010; 18(5):903-10.

12. Borba AMC, Lelis MAS, Brêtas ACP. Significado de ter incontinência urinária e ser incontinente na visão das mulheres. Texto Contexto Enferm. 2008; 17(3):527-35.

13. Higa R, Lopes MHBM. Fatores associados com a incontinência urinária na mulher. Rev Bras Enferm. 2005; 58(4):422-8.

14. Guarisi T, Pinto Neto AM, Osis MJ, Pedro AO, Paiva LHC, Faúndes A. Incontinência urinária entre mulheres climatéricas brasileiras: inquérito domiciliar. Rev Saúde Públ. 2001; 35(5):428-35.

15. Brasil. Ministério da Saúde. Informações de saúde (TABNET). Epidemiológicas e morbidades. Morbidade hospitalar do SUS por local de internação. Doenças do aparelho geniturinário [internet]. Prolapso genital feminino, 2014 [cited 2015 Apr 30]. Available from: http://www.datasus.gov.br/

16. Rett MT, Simóes JA, Herrmann MSCG, Gurgel MSC, Morais SS. Qualidade de vida em mulheres após tratamento da incontinência urinária de esforço com fisioterapia. Rev Bras Ginecol Obstet. 2007; 29(3):134-40.

17. Imamura M, Abrams P, Bain C, Buckley B, Cardozo L, Cody J, et al. Systematic review and economic modelling of the effectiveness and cost-effectiveness of non-surgical treatments for women with stress urinary incontinence. Health Technol Assess. 2010; 14(40):1-188.

18. Brasil. Conselho Nacional de Saúde. Resolução n ${ }^{\circ} 466 / 2012$ sobre pesquisas envolvendo seres humanos. Brasília (DF), 2013; DOU 12: 59.

19. Instituto Brasileiro de Geografia e Estatística (IBGE). Censo demográfico [internet]. 2010 [cited 2013 Apr 2]. Available from: http://cidades.ibge.gov.br
20. Brasil. Departamento de atenção básica. Sistema de Informação da Atenção Básica (SIAB). 2014 [cited 2015 May 7]. Available from: http://dab.saude. gov.br/portaldab/historico_cobertura_sf.php.

21. Tamanini JTM, Dambros M, D’Ancona CAL, Palma PCR, Netto Junior NR. Validação para o português do "International Consultation on Incontinence Questionnaire - Short Form” (ICIQ - SF). Rev Saúde Pública. 2004; 38(3):438-44.

22. Tamanini JTN, Tamanini MMM, Mauad LMQ, Auler AMBAP. Incontinência urinária: prevalência e fatores de risco em mulheres atendidas no Programa de Prevenção do Câncer Ginecológico. Boletim Epidemiológico Paulista. 2006; 3(34).

23. Gorenstein C, Andrade L. Validation of a Portuguese version of the Beck Depression Inventory and the State-Trait Anxiety Inventory in Brazilian Subjects. Braz J Med Biol Res. 1996; 29(4):453-7.

24. Lipp MEN. Inventário de sintomas de stress para adultos de LIPP (ISSL). São Paulo: Casa do Psicólogo; 2000.

25. World Health Organization. Defining the problem of overweight and obsesity. In: World Health Organization. Obesity: Preventing and managing the global epidemic: report of a WHO Consultation. Geneva: WHO; 2000. p.241-3.

26. Tamanini JT, Almeida FG, Girotti ME, Riccetto CL, Palma PC, Rios LA. The Portuguese validation of the International Consultation on Incontinence Questionaire - Vaginal Symptoms (ICIQ-VS) for Brazilian women with pelvic organ prolapsed. Int Urogynecol J Pelvic Floor Dysfunct. 2008; 19(10):1385-91.

27. Sensoy N, Dogan N, Ozek B, Karaaslan L. Urinary incontinence in women: prevalence rates, risk factors and impact on quality of life. Pak J Med Sci. 2013; 29(3):818-22

28. Ebbesen MH, Hannestad YS, Midthjell K, Hunskaar S. Diabetes and urinary incontinence - prevalence data from Norway. Acta Obstet Gynecol Scand 2007; 86(10):1256-62.

29. Waetjen EL, Liao S, Johnson WO, Sampselle CM, Sternfield B, Harlow SD, et al. Factors associated with prevalent and incident urinary incontinence in a cohort of midlife women: a longitudinal analysis of data for the Study of Women's Health Across the Nation (SWAN). Am J Epidemiol. 2007; 165(3):309-18

30. Gomes GV, Silva GD. Incontinência urinária de esforço em mulheres pertencentes ao programa de saúde da família de Dourados (MS). Rev Assoc Med Bras. 2010; 56(6):649-54.

31. Liu B, Wang L, Huang SS, Wu Q, Wu DL. Prevalence and risk factors of urinary incontinence among Chinese women in Shanghai. Int J Clin Exp Med. 2014; 7(3):686-96.

32. Hernández RRV, Aranda ER, Aznar CT. Urinary incontinence and weight changes during pregnancy and post partum: a pending challenge. Midwifery. 2013 29(12):e123-9.

33. Subak LL, Richter HE, Hunskaar S. Obesity and urinary incontinence: epidemiology and clinical research update. J Urol. 2009; 182 (6 Suppl):S2-7.

34. Sangsawang B. Risk factors for the development of stress urinary incontinence during pregnancy in primigravidae: a review of the literature. Eur J Obstet Gynecol Reprod Biol. 2014; 178:27-34.

35. Richter HE, Nygaard I, Burgio KL, Handa VL, Fitzgerald MP, Wren P, et al. Lower urinary tract symptoms, quality of life and pelvic organ prolapse: irritative bladder and obstructive voiding symptoms in women planning to undergo abdominal sacrocolpopexy for advanced pelvic organ prolapse. J Urol. 2007; 178(3 Pt 1):965-9

36. Scarpa KP, Herrmann V, Palma PC, Riccetto CL, Morais SS. Prevalence and correlates of stress urinary incontinence during pregnancy: a survey at UNICAMP Medical School, São Paulo, Brazil. Int Urogynecol J Pelvic Floor Dysfunct. 2006; 17(3):219-23

37. Van Brummen HJ, Bruinse HW, Van de Pol G, Heintz AP, Van der Vaart CH What is the effect of overactive bladder symptoms on woman's quality of life during and after first pregnancy? BJU Int. 2006; 97(2):296-300.

38. Torrisi G, Minini G, Bernasconi F, Perrone A, Trezza G, Guardabasso V, et al. A prospective study of pelvic floor dysfunctions related to delivery. Eur J Obstet Gynecol Reprod Biol. 2012; 160(1):110-5.

39. Dietz HP, Schierlitz L. Pelvic floor trauma in childbirth - myth or reality? Aust N Z J Obstet Gynaecol. 2005; 45(1):3-11.

40. Liang CC, Tseng LH, Horng SG, Lin IW, Chang SD. Correlation of pelvic organ prolapse quantification system scores with obstetric parameters and lower urinary tract symptoms in primiparae postpartum. Int Urogynecol J Pelvic Floor Dysfunct. 2007; 18(5):537-41. 
41. Hilde G, Stær-Jensen J, Siafarikas F, Engh ME, Brækken IH, Bø K. Impact of childbirth and mode of delivery on vaginal resting pressure and on pelvic floor muscle strength and endurance. Am J Obstet Gynecol. 2013; 208(1):50. e1-7.

42. Burgio KL, Zyczynski H, Locher JL, Richter HE, Redden DT, Wright KC. Urinary incontinence in the 12-month postpartum period. Obstet Gynecol. 2003; 102(6):1291-8.

43. Viktrup L, Rortveit G, Lose G. Risk of stress urinary incontinence twelve years after the first pregnancy and delivery. Obstet Gynecol. 2006; 108(2):24854.

44. Espuña-Pons M, Fillol M, Pascual MA, Rebollo P, Mora NA; Female Pelvic Floor Dysfunction Research Group (Grupo de Investigación en Disfunciones del Suelo Pélvico en la Mujer-GISPEM). Pelvic floor symptoms and severity of pelvic organ prolapsein women seeking care for pelvic floor problems. Eur J Obstet Gynecol Reprod Biol. 2014; 177:141-5.

45. Lammers K, Fütterer JJ, Prokop M, Vierhout ME, Kluivers KB. Diagnosing pubovisceral avulsions: a systematic review of the clinical relevance of a prevalent anatomical defect. Int Urogynecol J. 2012; 23(12):1653-64

46. Lawrence JM, Lukacz ES, Nager CW, Hsu JW, Luber KM. Prevalence and cooccurrence of pelvic floor disorders in community-dwelling women. Obstet Gynecol. 2008; 111(3):678-85.

47. Pauls RN, Silva WA, Rooney CM, Siddighi S, Kleeman SD, Dryfhout V, et al. Sexual function after vaginal surgery for pelvic organ prolapse and urinary incontinence. Am J Obstet Gynecol. 2007; 197(6):622.e1-7.

48. Rodrigues AM, Oliveira LM, Martins KF, Del Roy CA, Sartori MGF, Girão $\mathrm{MJBC}$, et al. Fatores de risco para o prolapso genital em uma população brasileira. Rev Bras Ginecol Obstet. 2009; 31(1):17-21.
49. Marinkovic SP, Stanton SL. Incontinence and voiding difficulties associated with prolapse. J Urol. 2004; 171(3):1021-8.

50. Palma T, Raimondi M, Souto S, Fozzatti C, Palma P, Riccetto C. Correlation between body mass index and overactive bladder symptoms in premenopausal women. Rev Assoc Med Bras. 2014; 60(2):111-7.

51. Chmaj-Wierzchowska K, Pięta B, Kotecka M, Michalak M, Sajdak S, Opala T. Three most important etiological factorsof occurrence of stress urinary incontinence in nulliparous pre- and postmenopausal Polish women. Ann Agric Environ Med. 2012; 19(3):581-5.

52. López M, Ortiz AP, Vargas R. Prevalence of urinary incontinence and its association with body mass index among women in Puerto Rico. J Womens Health. 2009; 18(10):1609-14.

53. Hunskaar S. A systematic review of overweight and obesity as risk factors and targets for clinical intervention for urinary incontinence in women. Neurourol Urodyn. 2008; 27(8):749-57.

54. Townsend MK, Danforth KN, Lifford KL, Rosner B, Curhan GC, Resnick $\mathrm{NM}$, et al. Incidence and remission of urinary incontinence in middle-aged women. Am J Obstet Gynecol. 2007; 197(2):167.e1-5.

55. Dallosso HM, McGrother CW, Matthews RJ, Donaldson MM; Leicestershire MRC Incontinence Study Group. The association of diet and other lifestyle factors with overactive bladder and stress incontinence: a longitudinal study in women. BJU Int. 2003; 92(1):69-77.

56. Subak LL, Johnson C, Whitcomb E, Boban D, Saxton J, Brown JS. Does weight loss improve incontinence in moderately obese women? Int Urogynecol J Pelvic Floor Dysfunct. 2002; 13(1):40-3

57. Brittain $\mathrm{KR}$, Shaw $\mathrm{C}$. The social consequences of living with and dealing with incontinence: a carers perspective. Soc Sci Med. 2007; 65(6):1274-83. 